\title{
OBJECT-BASED KNOWLEDGE REPRESENTATION OF FEMALE RELATED ISSUES FROM THE HOLY QURAN
}

\author{
Ku Ruhana Ku-Mahamud, Aniza Mohamed Din, Noraziah ChePa, \\ Faudziah Ahmad, Wan Hussain Wan Ishak, Farzana Kabir Ahmad \\ and Roshidi Din
}

School of Computing, Universiti Utara Malaysia, Malaysia ruhana@uum.edu.my; anizamd@uum.edu.my; aziah@uum.edu.my; fudz@uum.edu.my; hussain@uum.edu.my;farzana58@uum.edu.my; roshidi@uum.edu.my

\begin{abstract}
Focusing on the use of Semantic Network and Conceptual Graph (CG) representations, this paper presents an easy way in understanding concepts discussed in the Holy Quran. Quran is known as the main source of knowledge and has been a major source reference for all types of problems. However understanding the issues and the solution from the Quran is difficult due to lack of understanding of Quran literature. Meticulously, the Quran contains much important information related to female. However, this information are scattered and complexly linked. Technically, to extract and present the encapsulated knowledge on female matters in the Quran is a challenging task. Thus, this paper discusses on how to understand and represent the knowledge in an easy way. A total of 18 female terms are identified. Through the terms, the name of surah, verses number and text from the verses are gathered. The texts are then analyzed and clustered into specific issues. Result of the analysis that consists of extracted knowledge on female issues is presented in a systematic structure using Semantic Network and CG. The strength and advantages of both approaches are compared, discussed and presented.
\end{abstract}

Keywords: Knowledge Representation, Semantic Network, Conceptual Graph, Quran Female Term, Female Issues

\section{INTRODUCTION}

The Quran holds a large volume of unstructured subjects that is conceptually related between verses. Based on its English version, the Quran contains 114 surahs or chapters, 77,000 words and 6,200 verses that give answers and solutions to many problems faced by human. The vast amount of knowledge 
contained in the Quran makes it a good source of finding new information through identification of hidden trends, relationships, patterns, coincidences and associations. The process of extracting knowledge is known as text extraction and this topic has been a popular research area on texts document. However, researches on text extraction relating to the Quran are scarce. Text extraction has been seen as a difficult process because of the unstructured data. Text mining is an approach that has been widely used to analyze this type of data. Examples of research on text mining related to the Quran are grammatical parsing for the Quran (Salih, 2007; Al-Kharrat, 2007), categorization of modern standard Arabic verb valence based on Case Grammar (Al-Qahtani, 2005) and Quranic search engine based on semantic search (Raza, Rehan, Ahsan \& Khan, 2014).

Scholars on Quran in the past have been authoring books based on their personal knowledge to highlight various linguistic, stylistic, scientific, rhetorical, and many hidden discoveries from the Quran. However, there has been little attempt to present knowledge from the Quran based on computational methods such as object-based representations. An object-based methodology for knowledge representation uses objects of classes as its fundamental representational building block (Kelsey, Hartley \& Webster, 1997). This approach enables the logical reasoning based on graphical, visual and notations (Chein, Mugnier $\&$ Croitoru, 2013). Two commonly used object-based representation methods are conceptual graph and Semantic Network.

A conceptual graph (CG) is an abstract formalism for knowledge representation that consists of nodes known as concepts and conceptual relations, which are linked by edges. This structured representation has been introduced by John F. Sowa in 1976 (Sowa, 2008). At that point in time, CG is used to map natural language questions and assertion in order to build the conceptual schemas in database systems. Generally, CGs have been widely applied in various domain areas, for instance in artificial intelligence (AI), computer science and cognitive science (Sowa, 2008). The key idea of using this structured representation is to understand the complex Semantic Description (SD) of any information sources.

Several versions of CGs have been designed and implemented over the past thirty years. In the 1960s, graph-based semantic representations were popular among researchers especially in theoretical and computational linguistics. Semantic Networks, correlation nets and dependency graphs are some variations of graph representations that rely on different notations. Each of these graph-based semantic representations allows different ways of structuring 
knowledge. For example Semantic Network used "is a" and "a kind of" notation to link two related concepts, meanwhile dependency graph connects different nodes using edges without any explanation on the arc. Regardless of differences in their notations, the early graph-based representation managed to capture the underlying knowledge.

In this study, conceptual graph and Semantic Network were explored and used to present the extracted information related to female terms. Conceptual graph was used because as mentioned earlier, it is logically precise, readable and computationally tractable. Semantic Network is easy to represent and the presented structure can be easily understood by a layman. In addition, Semantic Network in this study is used to present the extracted information related to female terms because of its advantages in representing knowledge concept. Specifically, the paper explains how information related to female terms is extracted from the Quran, identifies significant female issues based on the extracted information, and presents the issues using the most appropriate diagrammatic representation of verses in the Quran.

\section{OBJECT-BASED KNOWLEDGE REPRESENTATION APPROACH}

There are several schemes used to represent knowledge starting from the fundamental logic-based approach, rule-based and the advanced object-based representation. Logic-based approach is widely used involving problems with prior knowledge such as experiences, while rule-based representation is usually used involving term-conditions cases. Object-based uses graphical notation to represent concept. This paper focuses on the use of objectbased representations which are Semantic Network and CG. Object-based representation is selected based on its strength particularly because it represents the concept clearer using graphical notation (Luger, 2009). Graphical notation facilitates the understanding in constructing the knowledge representation and could further improve the interpretability.

A Semantic Network is a graphical view of problem's important objects, properties and relationships. It views knowledge as a graph; with the nodes represent the facts or concepts and the arcs represent the relations or associations between concepts where both nodes and links are generally labeled (Luger, 2009; Hartley \& Barnden, 1997; Sowa, 2008). Semantic Network in ontology helps expresses vocabulary that is beneficial especially for human. Conceptually, Semantic Network is represented in a diagram consists of nodes, links (edges) and link labels. Nodes can be drawn as circles or ellipses or rectangles. It represents objects such as physical objects, concepts or 
situations. Links is drawn as arrows, represents relationships between objects. Link labels specify particular relations. A concept of semantic network is illustrated in Figure 1.

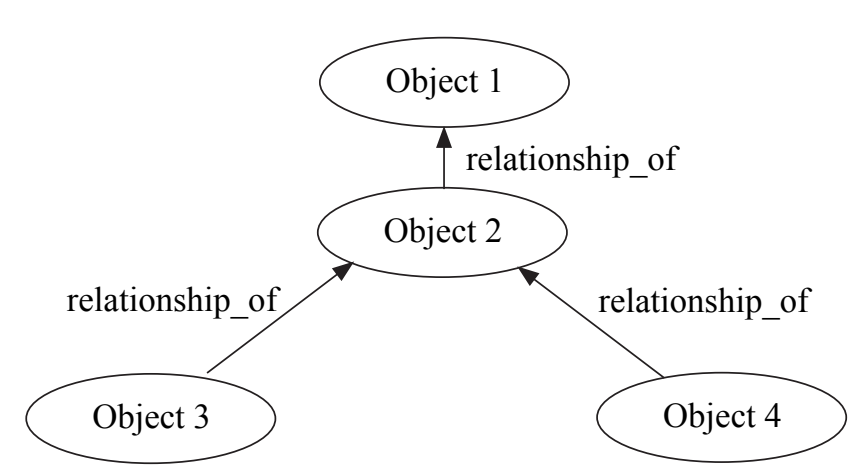

Figure 1. Semantic Network representation.

The strength of semantic is that, it has the ability to represent default values for categories. For example, Object 2 is a sub-object of Object 1 and will inherit features of Object 1 , which in this case is referred as default value. It also can convey some meaning in a transparent manner. Semantic Network has been widely used in various applications such as medical information retrieval (Koopman, Zuccon, Bruza, Sitbon \& Lawley, 2012), web navigation (Amiri, AleAhmad, Rahgozar \& Oroumchian, 2008), education (Moise \& Ionita, 2008) and agriculture (Wrzeciono, 2013). It has also been widely used in AI applications as it is easy to translate into PROLOG.

Naseem, Rahman and Sawar (2012) developed a Semantic Network based classifier of the Holy Quran. Noise characters such as dots, commas and semi colons from a verse are removed before the verse can be represented. The objects or concepts such as 'Allah', 'Muhammad', 'marriage' and 'divorce' in the verse are represented using links such as 'is a' or 'alias of'. This makes it easier to create a semantic network of any dimension using any description found in the verse to connect the concepts and objects. The classifier is then used to search for semantic association between the verses from the entire Quran, where the weights of each word are calculated before a topic can be identified. The technique proposed is found to produce a more accurate, versatile and robust results as compared to other statistical classifier.

Sharareh (2012) shared the same experience in applying Semantic Network to interpret verses of the Holy Quran. The main work involves a process of finding equivalent of Quranic words via semantic relations - when there are 
problems to find a proper equivalent word due to difficulties of recognizing the whole meaning of the word and its synonyms. Semantic Network has been used in the model to represent all the semantic relations of a word or rather the lexicalized concepts with other words in a network. These semantic relations enable the translator to choose the proper equivalents for synonymous words in the target language. In this work, it was shown that the application of Semantic Networks and relational models gave a broader view about the words and their relations in translation and interpretation works.

Abdullah, Selamat, Ibrahim, Ungku Chulan, Nasharuddin and Abdul Hamid (2009) used conceptual graph together with Concept Relational Model to strictly organize word classes into three main categories; concept, relation and attribute. The proposed model was able to reduce ambiguity in the meaning of a sentence. The result produced is accurate in relation extraction task. This would lead to better measurement of similarity for identical graphs and hence enable the improvement of graph integration.

CG evolved from Existential Graphs and semantic networks (Sowa, 2013). CG was introduced as early graph notations could not express full first-order logic. CG is a graph or network that consists of two kinds of nodes concepts and relations. The concept is represented in the rectangles while the relation is shown by oval. A type label that represents the type of relation: agent (Agnt), attribute (Attr), and Theme (theme). The nodes have arcs between them. The arcs are always directed, i.e. they have a direction and this is indicated by an arrow head.

Conceptual Graph Interchange Format (CGIF) is a standardization of CG that presents conceptual graphs as a graphic representation for logic. This representation is mainly used to handle interoperability, which is very important to represent distributed information in a conceptual framework (Kent, 2000). CGIF basically map the syntax of CGs, so it can allow communication between computer systems (Sowa, 2013; Puder, 1998; Martin, 2002). CGIF can be used to support the interoperability for CG based applications that needed in order to translate the instructions into various programming language. Current applications of CGs are including Multiple Fuzzy Ontology Mapping (Zhang, Yan, \& Ma, 2013) and knowledge representation for traditional medicine (Kamsu-Foguem, Diallo, \& Foguem, 2013).

Semantic Network and CG are two types of object-based knowledge representation that have been widely used in extracting meaningful and informative knowledge. Each has its own strengths and weaknesses. The 
comparison between both representations is shown in Table 1. The variables are taken from studies on Semantic Network and CG in representing knowledge (Sowa, 2008; Naseem et al., 2012; Sharareh, 2012).

Table 1

Comparison between Semantic Network and CG

\begin{tabular}{lcc}
\hline \multicolumn{1}{c}{ Variables } & Semantic Network & CG \\
\hline Accuracy & $\sqrt{ }$ & $\sqrt{ }$ \\
Completeness & $\sqrt{ }$ & $\sqrt{ }$ \\
Ease of Use & $\sqrt{ }$ & $\sqrt{ }$ \\
Clarity & & $\sqrt{ }$ \\
Complexity & & \\
\hline
\end{tabular}

From the table, it can be seen that both Semantic Network and CG can represent the concept accurately and completely. In terms of ease of use, Semantic Network is simpler and easier to be constructed and understood compared to CG as claimed by Sowa (2008) and Naseem et al. (2012). CG was developed after semantic network with the aim to represent complex problem involving full first-order logic (Sowa, 2008). Therefore, CG representation scheme is more complex and technical compared to Semantic Network. In terms of complexity, CG can represent the knowledge better, particularly involving problems which consist of quantifier, logic predicate and calculus.

\section{FEMALE RELATED ISSUES IN QURAN}

Women (or female) are a part of Muslim community. Women have their own basic rights that are recognized by Islam (Aisha, 2013; Rampoldi, 2014). Generally, Islam recognizes basic human right regardless of his nationality, his belief and where he lives. Among the rights are the right to life, the right to the safety of life, respect for the chastity of women, the right to a basic standard of life, freedom, justice, equality, and the right to co-operate and not to co-operate. These rights show that Islam practice equality that covers all aspect of life and all range of individuals be it male or female and either muslim or non-muslim. The manual on how to conduct any issues raise related to the human being can be obtained from the Holy Quran and Hadith.

The Holy Quran covers all aspects of female issues such as spiritual, social, economic and politics (Badawi, 1980). Similarly, Jawad (1998) classified the issues as legal, education, marriage, inheritance, and politics. As illustrated by 
Badawi (1980), the evidence and conduct of all aspects related to female are available in the Quran. In fact issues concerning female genital mutilation or female circumcision can be answered by referring to the Quran and Hadiths (Gomaa, 2013; Kutscher, 2011; Jawad, 1998).

According to Badawi (1980), in the aspect of spiritual for example, the Quran provide clear-cut evidence that woman is completely equated with man in the sight of God in terms of her rights and responsibilities. Taking religious obligation for example, woman is no different from man. However due to certain condition, women has been given certain advantages over man. In the social aspect, the Quran provide guidelines on the female responsibilities and their rights. In economy, women are not prohibited to get involved in economic activities. They are also having rights on their money, real estates, or other properties. In the aspect of politics, women have rights in elections as well as being nominated to political offices and to participate in public affairs. Therefore, the Quran is the best source of knowledge to describe and answer female related issues. This study focuses on knowledge representation of female related issues in the Quran using CG. This differs from the study by Naseem et al. (2012) and Sharareh (2012) where Semantic Network was used to represent knowledge from the Quran.

\section{METHODOLOGY}

The Quran contains too many information. A female related issue is only a part of information contains in the Quran. Furthermore, the information are scattered in various surahs. Referring to the right surah to retrieve specific verse that related to certain issues might be a problem. Semantic Network and CG approaches can be used to conceptualize the female related issues in Quran. The conceptualized information can give better overview about the issue, thus provide better understanding to the issues and its solution. This information can be used in teaching purposes and reference materials.

There are four steps in the method used in conducting this study; (i) identifying appropriate Quran search engine website, ii) verse extraction, (iii) verse analysis and issue identification, and (iv) development of Semantic Network and $\mathrm{CG}$ representations.

SearchTruth (www.searchtruth.com), Surah.My (www.surah. my), AL ISLAM (www.alislam.org/quran/search2), Guided Ways (www.guidedways.com/ search.php), and IslamiCity.com (www.islamicity.com/QuranSearch) are several examples of Quran search engines websites available on the Internet. These 
search engines support multiple languages such as English, Arabic, French, Indonesia, Spanish, Malay and Urdu. Appropriate search engine was selected based on its capability to support search multi-word phrases (Nanba \& Morishita, 2008), synonym search (Nadeem-Yasin et al., 2009), morphological search (Atwell et al., 2011), misspellings (Rachidi et al., 2003) and translation accuracy validated by experts.

Based on the evaluation of the search engines and expert advice, Surah. My is used in this study (Surah.My, n.d.) Furthermore, an analysis through bizinformation.com.my shows that Surah.My is actively being used in Malaysia and Indonesia. The traffic report shows that the website is active and frequently accessed.

Verses are then extracted using female related terms. This study has identified 18 female related terms which are nouns as follows: aunt, consort, damsel, daughter, divorcee, female, girl, lady, maid, maiden, mother, niece, queen, sister, whore, widow, wife and woman. In extracting the terms, plural and singular forms of the words are taken into consideration. The extraction of verses had been performed using the search engine provided by the Quran website. Terms and words are used interchangeably in this study. Extracted verses are analyzed by experts to identify issues and once issues are identified, Semantic Network and CG approaches are employed to represent the issues.

\section{FINDINGS AND DISCUSSION}

This section presents results on i) extracted information based on female terms, ii) significant issues based on extracted information, and iii) Semantic Network and Conceptual Graph representations.

\section{A. Extracted information based on female terms}

Verses are extracted from the Quran based on identified female terms which are nouns. Table 2 shows samples of the extracted information based on the term 'female'. There are a total of 240 verses that have been extracted.

The number of surah and verses related to the 18 female terms are depicted in Table 3. For example, the term 'female' when used in searching produced 32 verses obtained from 23 surahs. The term 'woman/women' produced the highest number of appearances compared to other terms, while 'aunt', 'queen', and 'niece' produced the lowest number of appearance. 
Table 2

Sample of Extracted Information

\begin{tabular}{llll}
\hline Juzu' & Surah & Verse No & Verse \\
\hline 4 & An-Nisaa & 11 & $\begin{array}{l}\text { Allah (thus) directs you as regards your Children's } \\
\text { (Inheritance): to the male, a portion equal to that } \\
\text { of two females ....... }\end{array}$ \\
6 & Al-Maaidah 38 & $\begin{array}{l}\text { As to the thief, Male or female, cut off his or her } \\
\text { hands: a punishment by way of example, from } \\
\text { Allah, for their crime: and Allah is Exalted in } \\
\text { power. }\end{array}$ \\
\hline *Source: www.surah.my &
\end{tabular}

Table 3

The Terms and Number of Appearance in Surahs and Verses

\begin{tabular}{|c|c|c|c|}
\hline No. & Term & Number of surah & Number of verses \\
\hline 1 & Aunt & 1 & 1 \\
\hline 2 & Consort & 3 & 7 \\
\hline 3 & Damsel & 1 & 2 \\
\hline 4 & Daughter & 12 & 17 \\
\hline 5 & Divorcee & 5 & 14 \\
\hline 6 & Female & 23 & 32 \\
\hline 7 & Girl & 2 & 2 \\
\hline 8 & Lady & 2 & 4 \\
\hline 9 & Maid & 3 & 3 \\
\hline 10 & Maiden & 2 & 2 \\
\hline 11 & Mother & 21 & 31 \\
\hline 12 & Niece & 1 & 1 \\
\hline 13 & Queen & 1 & 1 \\
\hline 14 & Sister & 6 & 11 \\
\hline 15 & Whore & 1 & 2 \\
\hline 16 & Widow & 2 & 3 \\
\hline 17 & Wife & 28 & 55 \\
\hline 18 & Woman & 30 & 91 \\
\hline
\end{tabular}

Table 4 shows several verses which contain more than one term. It can be seen that an issue could be related to several levels of the family tree and/or different age group. 
Table 4

Verses with Multiple Female Terms

\begin{tabular}{ll}
\hline Surah & Verse \\
\hline Al-Ahzab & 6: The Prophet is closer to the Believers than their own Wife, mother \\
selves, and his wives are their mothers. Blood-relations \\
among each other have closer personal ties, in the \\
Decree of Allah. Than (the Brotherhood of) Believers \\
and Muhajirs: nevertheless do ye what is just to your \\
closest friends: such is the writing in the Decree (of \\
Allah.. \\
30: Ladies said in the City: "The wife of the (great) Lady, wife \\
'Aziz is seeking to seduce her slave from his (true) self: \\
Truly hath he inspired her with violent love: we see she \\
is evidently going astray." \\
40: Behold! thy sister goeth forth and saith, 'shall I show Sister, mother \\
you one who will nurse and rear the (child)?' So We \\
brought thee back to thy mother, that her eye might be \\
cooled and she should not grieve. Then thou didst slay a \\
man, but We saved thee from trouble, and We tried thee \\
in various ways. Then didst thou tarry a number of years \\
with the people of Midian. Then didst thou come hither \\
as ordained, O Moses! \\
Taha \\
50: O Prophet! We have made lawful to thee thy wives to Wife, daughter, \\
whom thou hast paid their dowers; and those whom thy aunt, woman \\
right hand possesses out of the prisoners of war whom \\
Allah has assigned to thee; and daughters of thy paternal \\
uncles and aunts, and daughters of thy maternal uncles \\
and aunts, who migrated (from Makka) with thee; and \\
any believing woman who dedicates her soul to the \\
Prophet if the Prophet wishes to wed her;- this only for \\
thee, and not for the Believers (at large); We know what \\
We have appointed for them as to their wives and the \\
captives whom their right hands possess;- in order that \\
there should be no difficulty for thee. And Allah is Oft- \\
Forging, Most Merciful \\
Al-Ahzab
\end{tabular}

\section{B. Significant issues based on extracted information}

The extracted verses were studied and issues related to information in the verses were identified based on selected keywords as displayed in Table 5. Issues highlighted are inheritance, punishment, and marriage, together with examples of the surah and verses related to them. 
The issue of inheritance, for example, is highlighted in the Quran to reflect fairness in assets allocation of a deceased to respective descendants and to ensure women and children are treated fairly. The issue of marriage however, highlighted the rights and obligations of all married couples, which also includes the affairs of financial and non-financial matters. This leads to overlapping of issues such as inheritance and divorce matters. Further work will be done to tackle this problem.

\section{Table 5}

\section{Examples of Significant Issues}

\begin{tabular}{|c|c|c|}
\hline Issue & Surah & Verse \\
\hline \multirow[t]{4}{*}{ Inheritance } & An-Nisaa' & $\begin{array}{l}\text { 11: Allah (thus) directs you as regards your Children's } \\
\text { (Inheritance): to the male, a portion equal to that of two } \\
\text { females ....... }\end{array}$ \\
\hline & An-Nisaa' & $\begin{array}{l}\text { 12: In what your wives leave, your share is a half, if they } \\
\text { leave no child; but if they leave a child, ye get a fourth; } \\
\text { after payment of legacies and debts ....... }\end{array}$ \\
\hline & An-Nisaa' & $\begin{array}{l}176 \text { : They ask thee for a legal decision. Say: Allah } \\
\text { directs (thus) about those who leave no descendants or } \\
\text { ascendants as heirs. If it is a man that dies, leaving a sister } \\
\text { but no child, she shall have half the inheritance ...... }\end{array}$ \\
\hline & & $\cdots$ \\
\hline \multirow[t]{3}{*}{ Punishment } & Al-Maidah & $\begin{array}{l}\text { 38: As to the thief, male or female, cut off his or her } \\
\text { hands: a punishment by way of example, from Allah, for } \\
\text { their crime: and Allah is Exalted in power. }\end{array}$ \\
\hline & An-Nuur & $\begin{array}{l}\text { 2: The woman and the man guilty of adultery or } \\
\text { fornication,- flog each of them with a hundred stripes: } \\
\text { Let not compassion move you in their case, in a matter } \\
\text { prescribed by Allah, if ye believe in Allah and the } \\
\text { Last Day: and let a party of the Believers witness their } \\
\text { punishment. }\end{array}$ \\
\hline & An-Nuur & $\begin{array}{l}\text { 4: And those who launch a charge against chaste } \\
\text { women, and produce not four witnesses (to support } \\
\text { their allegations),- flog them with eighty stripes; and } \\
\text { reject their evidence ever after: for such men are wicked } \\
\text { transgressors;- }\end{array}$ \\
\hline
\end{tabular}

(continued) 


\begin{tabular}{|c|c|c|}
\hline Issue & Surah & Verse \\
\hline \multirow[t]{4}{*}{ Marriage } & An-Nisaa' & $\begin{array}{l}\text { 23: Prohibited to you (For marriage) are:- Your mothers, } \\
\text { daughters, sisters; father's sisters, Mother's sisters; } \\
\text { brother's daughters, sister's daughters; foster-mothers } \\
\text { (Who gave you suck), foster-sisters; your wives' mothers; } \\
\text {..... }\end{array}$ \\
\hline & An-Nuur & $\begin{array}{l}\text { 32: Marry those among you who are single, or the } \\
\text { virtuous ones among yourselves, male or female: if } \\
\text { they are in poverty, Allah will give them means out of } \\
\text { His grace: for Allah encompasseth all, and He knoweth } \\
\text { all thing }\end{array}$ \\
\hline & Al-Ahzab & $\begin{array}{l}\text { 49: O ye who believe! When ye marry believing women, } \\
\text { and then divorce them before ye have touched them, no } \\
\text { period of 'Iddat have ye to count in respect of them: so } \\
\text { give them a present. And set them free in a handsome } \\
\text { manner. }\end{array}$ \\
\hline & $\ldots \ldots$ & $\ldots \ldots$ \\
\hline
\end{tabular}

\section{Semantic Network and CG representation}

A verse from An-Nisaa' (4:11) is used as an example to show the Semantic Network representation as shown in Figure 2. The full verse is as follows:

“Allah (thus) directs you as regards your Children's (Inheritance): to the male, a portion equal to that of two females: if only daughters, two or more, their share is two-thirds of the inheritance; if only one, her share is a half. For parents, a sixth share of the inheritance to each, if the deceased left children; if no children, and the parents are the (only) heirs, the mother has a third; if the deceased Left brothers (or sisters) the mother has a sixth. (The distribution in all cases ('s) after the payment of legacies and debts. Ye know not whether your parents or your children are nearest to you in benefit. These are settled portions ordained by Allah. and Allah is All-knowing, All-wise" (Holy Quran, Surah An-Nisaa', verse 11).

The verse describes the faraid system for a deceased, specifically highlighting the portion of inheritance for the deceased children and parents. It also describes the allocation of inheritance in the case of a deceased with no heir. From the figure, all facts - physical objects and concept such as 'daughter', 'mother', 'half share' and 'two-thirds share' are represented as nodes. These facts can be considered as topics that can be used as keywords for searching. The arcs in the network describe the relationship of each node and can be used as a link in a situation where we have a number of verses highlighting similar issue. 


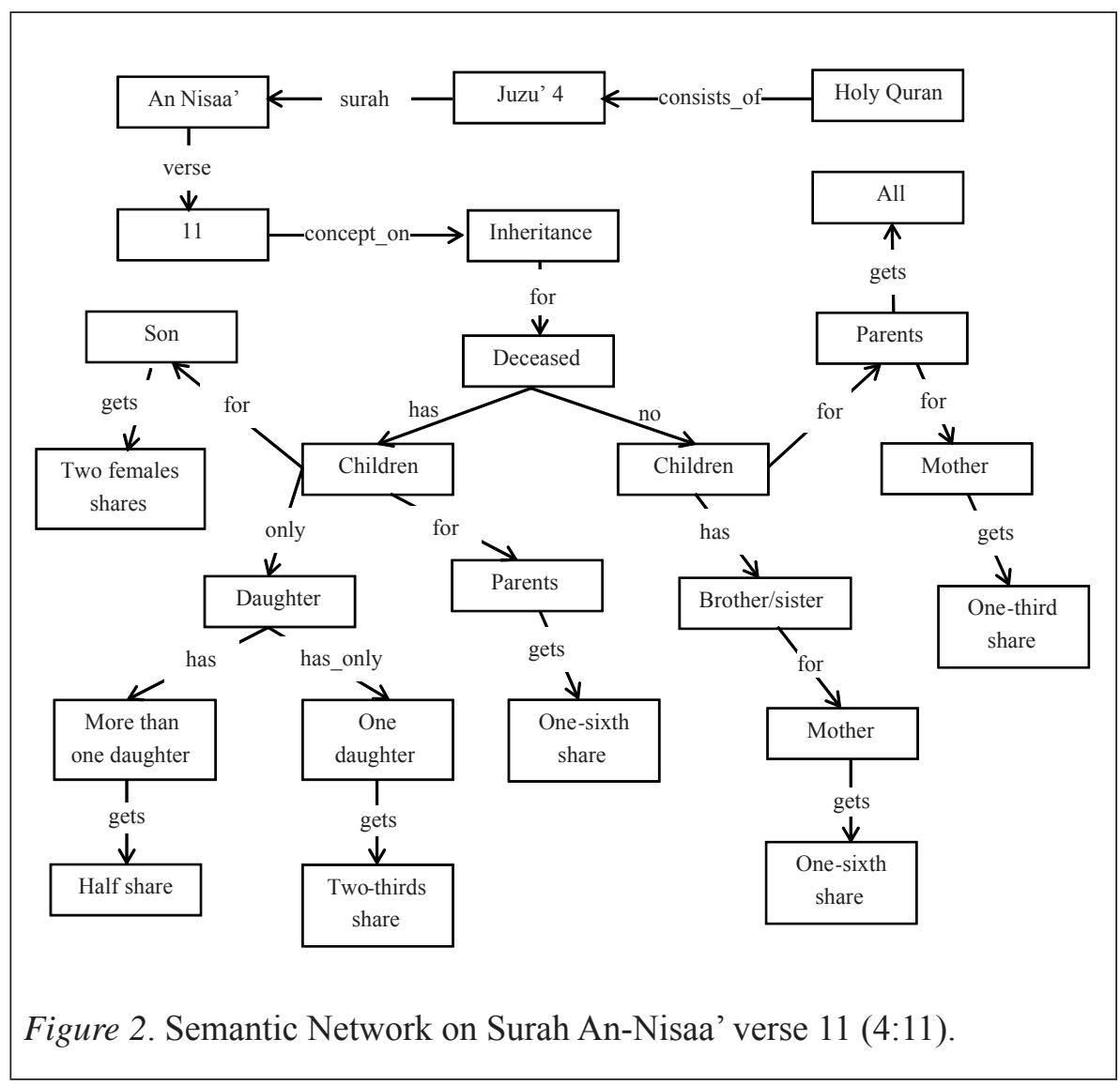

The Holy Quran consists of verses which describe various issues. Some of the issues are stressed a number of times in the Quran to indicate its importance. Having a graphical view of all the related verses on issues in the Holy Quran gives a clear picture on the issues described. This parallels with a statement by Sowa (2008) that network notations are easy for people to read as graphs keep all the information about an entity in a single node and show the related information by links connected directly to the node. Combining the representation of different verses is also easy as it did not disturb the structure of the existing networks.

Part of the same verse is also presented using CG as shown in Figure 3. Figure 3 has been constructed based on the Surah An-Nisaa' verse, 11. Quite different from Semantic Network, CG represents the knowledge in the form of concepts and relations. On top of that, $C G$ offers a logic representation to facilitate the processing of text. This figure has describes the knowledge which has been extracted from the Holy Al-Quran by representing it into nodes, attributes, 
themes, and actions. CG has been used to represent elements in verse 11, by identifying nouns, verbs, adjectives, and adverbs, while the relation between nodes represents some syntactic relation (including prepositions) between the concepts. For example the phrase Holy Quran is consists of Juzu' has been represented into three concepts and agent is used to link them.

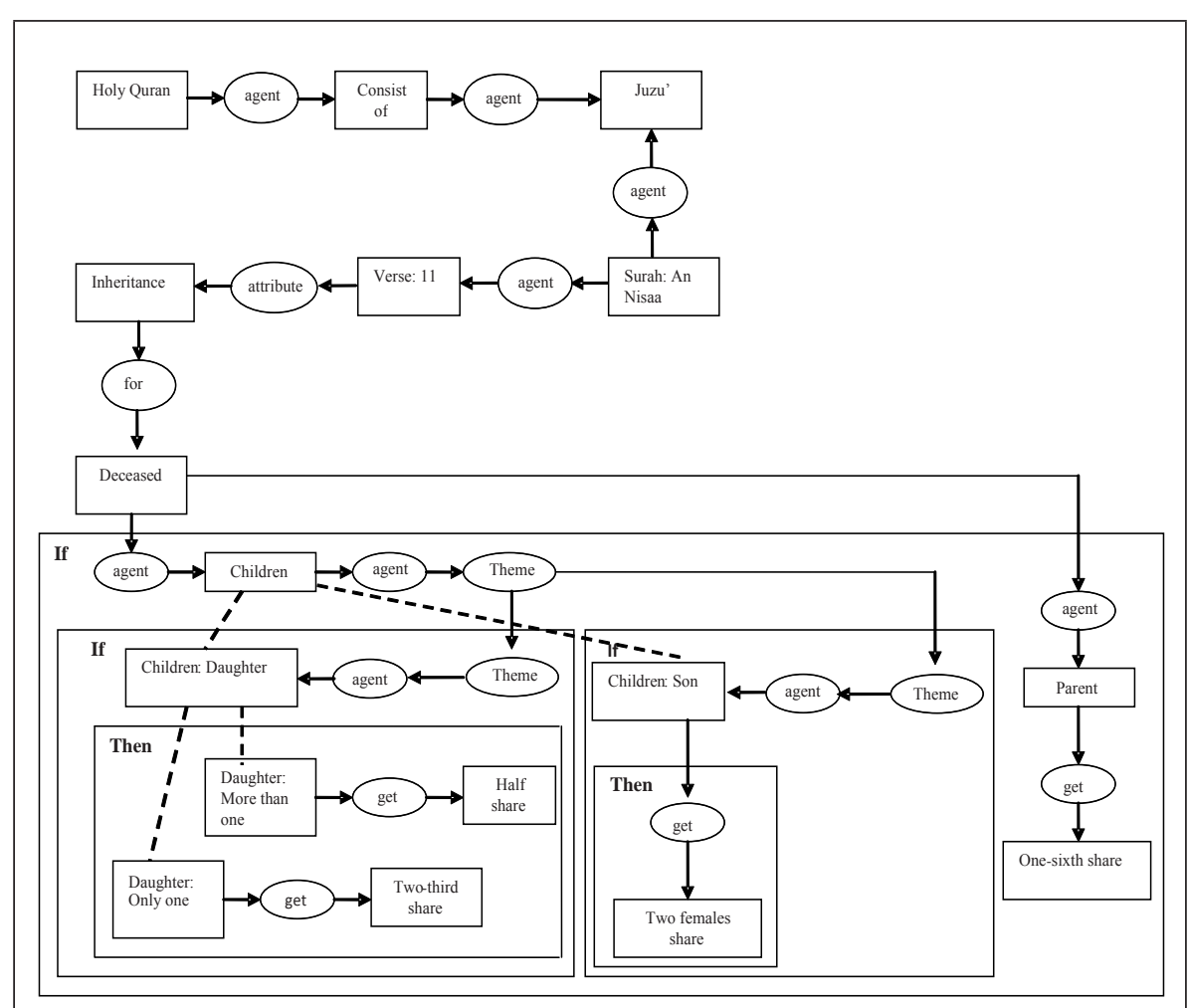

Figure 3. CG representation of Surah An-Nisaa' verse 11 (4:11).

\section{CONCLUSION}

Conceptual graph and Semantic Network representations were used in representing issues extracted from verses in the Quran. Visual information from both approaches can be used as a quick reference and serve as decision support tool for female related problem. Both methods have advantages and disadvantages in representing female issues from the verses. Semantic network has produce presentation that is simple and precise. However, CG has been found to be more logically precise, readable and computationally tractable. 
Future work in this area will focus on resolving methods in extracting issues and classifying verses according to the issues. Extensions on CG to CGIF in representing the issues will be explored.

\section{ACKNOWLEDGEMENTS}

The author would like to acknowledge the Ministry of Higher Education and Research and Innovation Management Centre of Universiti Utara Malaysia for the management and financial support. Appreciation also goes to Associate Professor Dr. Hj. Abd Aziz Bin Hj. Hanafi, Kolej Universiti Insaniah (KUIN), Kedah, Malaysia for the technical support regarding Quran.

\section{REFERENCES}

Abdullah, R., Selamat, M. N., Ibrahim, H., Ungku Chulan, U. C., Nasharuddin, N. A., \& Abdul Hamid, J. (2009). Semantics representation in a sentence with concept relational model (CRM). Journal of Information and Communication Technology, 8, 55-65.

Aisha, F. (2013). Rights of women in Islam (In the light of Holy Quran and Hadiths). Samajbodh, 3(1), 33-42.

Al-Kharrat, A. M. (2007). Eraab Mushkil al-Quran (نآرقلا لكشم بارع!) Syntactic analysis of the Quran. Also available online at http://www. qurancomplex.com

Al-Qahtani, D. (2005). Semantic valence of Arabic verbs. Beirut: Librairie du Liban Publishers.

Amiri, H., AleAhmad, A., Rahgozar, M., \& Oroumchian, F. (2008). Keyword suggestion using conceptual graph construction from Wikipedia rich documents. Proceedings of the International Conference on Information and Knowledge Engineering.

Atwell, E. S., Brierley, C., Dukes, K., Sawalha, M., \& Sharaf, A. (2011). An artificial intelligence approach to Arabic and Islamic content on the Internet. Proceedings of the 3rd National Information Technology Symposium.

Badawi, J. (1980). The status of women in Islam: Basic principles. Retrieved from http://islamicweb.com

Chein, M., Mugnier, M. L., \& Croitoru, M. (2013). Visual reasoning with graph-based mechanisms: The good, the better and the best. The Knowledge Engineering Review, 28(3), 249-271.

Gomaa, A. (2013). The Islamic view on female circumcision. African Journal of Urology, 19, 123-126. 
Hartley, R. \& Barnden, J. (1997). Semantic networks: Visualizations of knowledge. Trends in Cognitive Science, 1, 169-175.

Jawad, H. A. (1998). The rights of women in Islam: An authentic approach. Great Britain: MacMillan Press.

Kamsu-Foguem, B., Diallo, G., \& Foguem, C. (2013). Conceptual graphbased knowledge representation for supporting reasoning in African traditional medicine. Engineering Applications of Artificial Intelligence, 26(4), 1348-1365.

Kelsey, R. L., Hartley, R. T., \& Webster, R. B. (1997). An object-based methodology for knowledge representation in SGML. Proceedings of the 9th International Conference on Tools with Artificial Intelligence, 304-311.

Kent, R. E. (2000). Conceptual knowledge markup language: An introduction. Netnomics, 2, 139-169.

Koopman, B., Zuccon, G., Bruza, P., Sitbon, L., \& Lawley, M. (2012). Graphbased concept weighting for medical information. Proceedings of the Australasian Document Computing Symposium, 80-87.

Kutscher, J. (2011). Towards a solution concerning female genital mutilation: An approach from within according to Islamic legal opinions. Religion and the Body, 23, 216-236.

Luger, G. F. (2009). Artificial intelligence: Structures and strategies for complex problem solving. Boston: Pearson Addison-Wesley.

Martin, P. H. (2002). Knowledge representation in CGLF, CGIF, KIF, Frame$C G$ and Formalized-English. Proceedings of the $10^{\text {th }}$ International Conference on Conceptual Structures, 77-91.

McDermott, D. (1976). Artificial intelligence meets natural stupidity. ACM SIGART Bulletin, 57, 4-9.

Moise, G., \& Ionita, L. (2008). Educational semantic networks and their applications. Matematica-Informatica, LX (2), 77-85.

Nadeem-Yasin, M. Hikmat, U. K., Saeed, M. I., \& Khiyal, M. S. H. (2009). Relational wordnet model for semantic search in Holy Quran. Proceedings of Emerging Technologies, 29-34.

Nanba, H., \& Morishita, S. (2008). Searching for illustrative sentences for multiword expressions in a research paper database. Lecture Notes in Computer Science, 5362 Springer 2008, 114-123.

Naseem, S., Rahman, A., \& Sawar, M. J. (2012). Semantic network based classifier of Holy Quran. International Journal of Computer Applications, 39(5), 43-47.

Puder, A. (1998). Mapping of CGIF to operational interfaces. Proceedings of International Conference on Conceptual Structures, 119-126. 
Rachidi, T., Bouzoubaa, M., El-Mortaji, L., Boussouab, B., \& Bensaid, A. (2003). Arabic user search query correction and expansion. Proceedings of Competences Conference of Information Technology.

Rampoldi, M. (2014). Female sovereigns in Islamic states. Berlin: Epubli $\mathrm{GmbH}$.

Raza, S. A., Rehan, M., Farooq, A., Ahsan, S. M., \& Khan, M. S. (2014). An essential framework for concept based evolutionary Quranic search engine. Science International (Lahore), 26(1), 181-184.

Salih, Bahjat Al-wahhab (2007). Al-eraab al-Mufassal Li-Kitab Allah al-

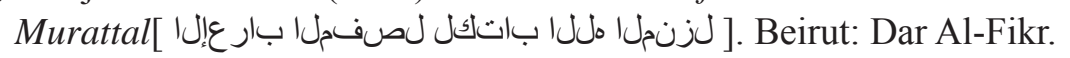

Sharareh, S. S. (2012). Transinterpretation of Quranic words based on semantic network theory and devising their database. Proceedings of the Asian Conference on Arts and Humanities, 405-414.

Sowa, J. F. (2008). Conceptual graphs. In F. van Harmelen, V. Lifschitz, \& B. Porter (Eds.), Handbook of knowledge representation pp. 213-237. Amsterdam, The Netherlands: Elsevier Science.

Sowa, J. F. (2013). From existential graphs to conceptual graphs. International Journal of Conceptual Structures and Smart Applications, 1(1), 39-72.

Surah.My. (n.d.). Terjemahan al-Quran bahasa Melayu. Retrieved from http:// www.surah.my

Tanzil. (2011). Tanzil Project. Retrieved from http://tanzil.net.

Woods, W. A. (1975). What's in a link: Foundations for Semantic Networks. In D. G. Bobrow \& A. Collins (Eds.), Representation and understanding. New York: Academic Press.

Wrzeciono, P. (2013). Automatic indexing and creating semantic networks for agricultural science papers in the Polish language. Proceedings of the $37^{\text {th }}$ Annual Computer Software and Applications Conference Workshops, 356-360.

Zhang, L., Yan, L., \& Ma, Z. M. (2013). A conceptual graph based approach for mappings among multiple fuzzyontologies. Journal of Web Engineering Archive, 12(3-4), 215-231. 